\title{
Literatura europejska - niemieckie dyskusje na przełomie wieków XVIII i XIX $^{* *}$
}

\author{
DOI: http://dx.doi.org/10.12775/LC.2015.020
}

Streszczenie. Artykuł poświęcony jest dyskusjom wokół pojęcia literatury europejskiej, względnie literatury światowej, które toczyły się wśród pisarzy i intelektualistów niemieckich na przełomie XVIII i XIX wieku. Historyczne koncepcje stanowią następnie dla autora inspirację do naszkicowania własnej propozycji wyjścia poza wąskie ramy tradycyjnej, ukształtowanej w XIX wieku (niemieckiej) filologii narodowej w kierunku „historii świadomości literackiej”.

S ł ow a kl u c zowe : literatura niemiecka; literatura europejska; literatura światowa; J. W. Herder; A. W. Schlegel; F. Schlegel; Novalis; J. W. Goethe; świadomość literacka.

A b s t r a c t . European literature: German debates at the turn of the $19^{\text {th }}$ century. The author analyses the debates on the concept of "European/world literature" which took place in the $18^{\text {th }}$ and early $19^{\text {th }}$ century in German intellectual and literary circles. He attempts to demonstrate that the idea of European literature is relatively young. Historical debates give the author an opportunity to propose a way of writing the history of German literature beyond the limiting framework of national philology. On the basis of the historical debates discussed in the article, the author proposes to move

\footnotetext{
* Autor był profesorem germanistyki na Uniwersytecie Warszawskim i na Uniwersytecie Mikołaja Kopernika w Toruniu (1979-2007), profesorem wizytującym w Szwajcarii, Francji i na licznych uniwersytetach w Niemczech, profesorem uniwersytetu w Usti nad Labem (2009-2011), Akademii im. Jan Długosza w Częstochowie (2011/2012), obecnie jest profesorem Akademii Pomorskiej w Słupsku. Opublikował m.in. książki: Diltheys Erlebnisbegriff. Entstehung, Glanzzeit und Verkümmerung eines literaturhistorischen Begriffs (1972); Einführung in die Ästhetik Adornos (1979); Od Diltheya do Adorna. Studia z estetyki niemieckiej (1986); Dreißig Silberlinge. Denunziation in Gegenwart und Geschichte (2000); Harminc eüst. Besúgások és árulások (2001, nowe zmienione wydanie 2012); Polen und Juden zwischen 1939 und 1968. Jedwabne und die Folgen (2004); Literatur- und Kulturtransfer als Politikum am Beispiel Volkspolens (2006). E-mail: sauerland@uw.edu.pl.

** Tekst jest zmienioną wersją artykułu Europäische Literatur als Begriff, [w:] Die kulturelle Eigenart Europas, red. G. Buchstab, Freiburg-Basel-Berlin 2010, s. 165-177.
} 
beyond the limiting $19^{\text {th }}$-century concept of (German) national philology towards "a history of literary consciousness."

Key words : German literature; European literature; world literature; J. W. Herder; A. W. Schlegel; F. Schlegel; Novalis; J. W. Goethe; literary consciousness.

elem artykułu jest przedstawienie głównych tendencji w dyskusji nad pojęciem literatury europejskiej, jaka toczyła się w drugiej połowie XVIII wieku w obszarze niemieckojęzycznym. Często nawiązuje się - nie tylko w literaturoznawstwie niemieckim - do pochodzącego z tego okresu pojęcia „literatury światowej”, przypisywanego Goethemu. Nie można jednak tego pojęcia wyizolować - co ma często miejsce - z kontekstu historycznego, z jakiego się ono wyłoniło. Niemieckiemu literaturoznawstwu udało się wprowadzić termin Weltliteratur do międzynarodowej dyskusji. Literaturoznawcy biorą przy tym to pojęcie na ogół bardzo dosłownie, jako synonim „literatury powszechnej”, nie dostrzegając, że Goethe miał w istocie na uwadze coś, co określamy obecnie jako „literaturę europejską”, mimo iż w Dywanie Zachodu i Wschodu odwoływał się do piśmiennictwa staroperskiego (podążając tu zresztą śladami Friedricha Schlegla, któremu kultura niemiecka zawdzięcza zwrócenie uwagi na Orient; to dzięki Schleglowi do kanonu zainteresowań literaturoznawstwa niemieckiego wszedł sanskryt). Moim zdaniem nie należy jednak tego poszerzenia horyzontu przeceniać. Wrażliwość na fenomen literatury światowej zaczyna się w Niemczech dopiero w połowie XIX wieku, co pokażę na wybranych przykładach.

Gdy Martin Opitz pisał swoją rozprawę Buch von der Deutschen Poeterey (Poetyka niemiecka, 1624), myślał o tworzeniu literatury w języku niemieckim. Pojmował je jako swego rodzaju współzawodnictwo z Włochami i Francuzami, którzy już wcześniej zaczęli uprawiać literaturę piękną w swoich językach narodowych, a nie wyłącznie po łacinie. Opitzowi z pewnością nawet się nie śniło, że przyczyni się do powstania pojęcia literatury europejskiej. Istniała dla niego literatura łacińska, a także grecka, i to je za wzór powinien według Opitza obrać sobie każdy, kto chciałby być zaliczany do ludzi wykształconych. Właśnie literatura łacińska pomogła jego zdaniem wielu znacznym „mężom wybić się”, uratować się w barbarzyńskich czasach ${ }^{1}$. Literatura niemiecka mogąca mierzyć się z zachodnimi sąsiadami wykształciła się dopiero w drugiej połowie XVIII wieku. Natomiast pojęcie literatury, względnie beletrystyki, europejskiej upowszechniło się w języku niemieckim na przełomie XVIII i XIX wieku. Za reprezentatywny przykład tego procesu mogą posłużyć wywody Herdera w jego Listach wzywajacych do krzewienia człowieczeństwa (Briefe zur Beförderung der Humanität) z 1790 roku. W Liście 84 Herder mówi o „powstaniu nowego smaku w Europie”, mając na myśli epokę wczesnośredniowieczną. Po tym, jak upadła poezja Greków i Rzymian, nabrało kształtów coś innego, nowego: początkowo były to hymny chrześcijańskie, u których „podłoża spoczywały owe stare hebrajskie Psalmy”2. Owo żydowskie pod-

1 M. Opitz, Buch von der Deutschen Poeterey, Halle 1955, s. 16. Była to pierwsza poetyka napisana w języku niemieckim.

2 Cyt. za: J. G. Herder, Briefe zur Beförderung der Humanität, red. H. D. Irmscher, Frankfurt am Main 1991, s. 449. Przekład tłumaczki (ten esej Herdera nie był dotąd tłumaczony na język polski). 
łoże szybko jednak zostało porzucone, ponieważ zaczęto pojmować psalmy „wyłącznie na sposób chrześcijański”3. Zmieniły się one również za sprawą muzyki i śpiewu, tak że mogły

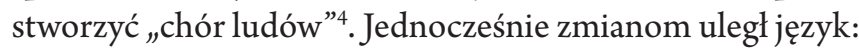

Podczas gdy u Greków i Rzymian nie zanikł ów stary, autentyczny rytm, według którego każda sylaba posiadała swoją miarę czasową podług długości, oraz tonacje, to przepadł on wkrótce potem, jak pokazują hymny chrześcijańskie. Mało na niego zważano, przeciwnie: podążano, ponieważ wszystko było obliczone na popularność, za pospolitą wymową, za jej okresami i kadencjami, krótkomówiąc,za brzmieniem miłym dla pospolitego uchas.

Pospolitości nie należy tu rozumieć negatywnie, ponieważ Herder przypisuje ludowi pierwotne, czytaj: poetyckie, siły. Jednak owe nowe zjawiska u zarania epoki poantycznej nie oznaczały jeszcze jego zdaniem początku literatury europejskiej. Aby mogło do tego dojść, musiało najpierw zaistnieć wzajemne powiązanie lub wręcz konkurencja „europejskich ludów”. „Pierwsza iskra odradzającej się kultury” zrodziła się w Hiszpanii pod wpływem arabskim. Tam, według Herdera, widzimy „pierwszy promień nowej poetyckiej jutrzenki Europy!”’ „Początek kultury europejskiej” - czytamy dalej w Uzupetnieniu - różni się od epoki greckiej tym, że rozwinęła się tu „s wo b od a myśli”, ku jakiej „poezji Dawnych nie wolno było skierować swoich żagli”, ale niezbędne było - pisze Herder - aby „wszystkie narody Europy” wyzwoliły się od „despotyzmu ł a c i n y , aby „słuchały w swoich językach narodowych rzeczy błyskotliwych, głębokich, pełnych wdzięku" i ćwiczyły dzięki temu swój „rozum”. Pierwsze kroki ku temu poczynił język prowansalski. Herder poświęcił więc konsekwentnie następny list-esej Wplywowi Prowansalczyków na europejska kulturę i poezję. Ich sztukę wersyfikacyjną

przejęły wszystkie sąsiednie ludy; stała się ona wzorcem poezji wszystkich ludów południowych, pod pewnymi względami nawet Anglików i Niemców, gdyż wraz z cesarzami z dynastii szwabskiej prowansalska sztuka poetycka dotarla także do Niemiec. Minnesingerzy to nasi Prowansalczycy. W czasach Dantego w języku włoskim istniało już siedem gatunków tej sztuki: sonet, ballada, canzona, redondilla, madrygał, sirventes, oktawa. Od tego czasu licznie się one rozmnożyły, wielokrotnie ulegały zmianom, ale język włoski zawsze pozostał wierny mierze, którą w epoce Dantego, Boccaccia i Petrarki narzuciła mu poezja prowansalska. Wersyfikacja Greków i Rzymian, choć wiele razy jej próbowano, nigdy nie przyjęła się we Włoszech, Hiszpanii ani we Francji'.

3 Ibidem, s. 453.

4 lbidem, s. 454.

${ }^{5}$ Ibidem, s. 454 i n.

6 Ibidem, s. 470.

7 Ibidem, s. 474.

8 Ibidem, s. 482. Herder relatywizuje, jak widać, epokę antycznej Grecji, wpisując się zarazem w nurt głębokiego zainteresowania Helladą, jakie panowało w ówczesnej kulturze niemieckiej. Odkrycie antyku zawdzięczamy oczywiście humanizmowi, zasługą Niemców jest przede wszystkim odróżnienie antyku greckiego od rzymskiego (szczególne zasługi miał tu Winckelmann ze swoją Geschichte der Kunst des Althertums). Niemcy drugiej połowy XVIII wieku mogli się w tak pojętej antyczności greckiej przejrzeć jak w lustrze: Hellada była, podobnie jak ówczesne Niemcy, złożona z wielu państw. Ważna była także opozycja wobec świata romańskiego, a w jego obszarze przede wszystkim wobec Francji. Świat romański Niemcy widzieli jako czerpiący z ducha Rzymu, a nie Grecji. Winckelmann podkreślał, że Rzym pod względem kultury był zaledwie imitacją dziedzictwa greckiego.

9 Ibidem, s. 484. 


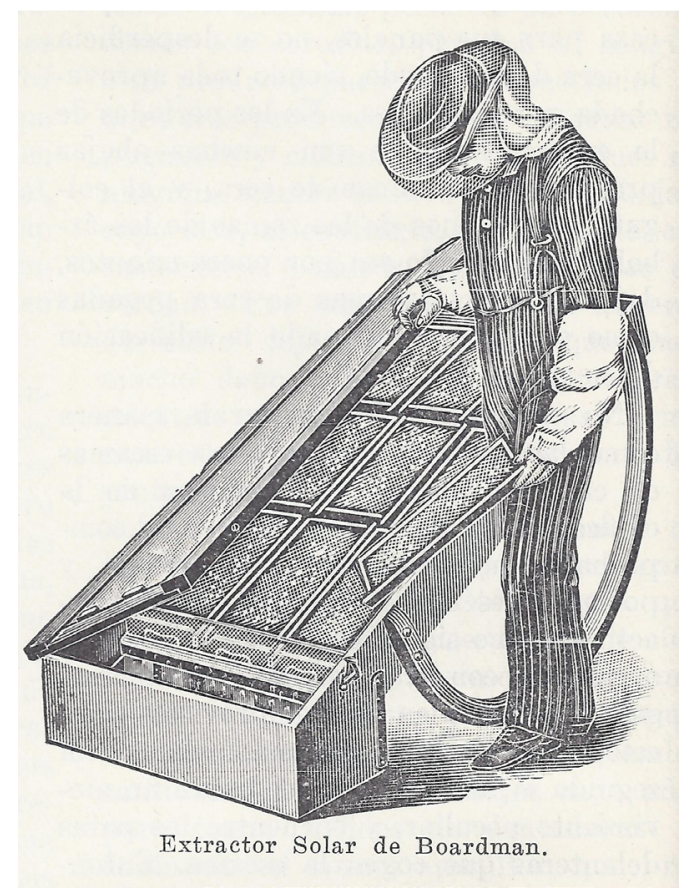

Literatura włoska była, w odróżnieniu od greckiej, przeznaczona dla przyjemności, kochała afekt, powtórzenie. Stąd tu właśnie dokonał się rozwój opery. Inna sytuacja miała miejsce we Francji, gdzie powstała oryginalna kultura opowiadania. Herder wskazuje w tym miejscu na Montaigne’a, Marmontela i Diderota. Francuzi rozwinęli język, który „we wszystkim, nawet w najpoważniejszych naukach, osiągnął ową rześką precyzję, ową klarowność i uprzejmość, które pobudziły do naśladowania niemal całą Europę. Geniusz ich sposobu pisania nazywa się discours. Wszystko jest dla nich klarowne; potrafią i mogą o p o w i e d z i e ć to, co wiedzą, jak też to, czego nie wiedzą"10. Mamy tu do czynienia z kwestią reprezentacji, a ta według Herdera nie istnieje bez pewnej powierzchowności. Francja pragnie błyszczeć, dlatego potrzebuje wzroku „innych, najlepiej mówiąc, pisząc i d z i a łaj ą c na oczach samego Wszechświata" ${ }^{11}$. Bez tego dążenia Francuzi nie rozwinęliby swego stylu i swojej szczególnej formy sztuki scenicznej. Tę część swoich rozważań Herder kończy podsumowaniem zatytułowanym $O$ wartości poezji czasów średnich $w$ Europie. Poezja miała według niego oddziałać łagodząco na ludy barbarzyńskie. Mimo sprzecznych interesów „wszystkie ludy rzymsko-chrześcijańskiej Europy” znalazły siępo pewnym czasie „na polu bitewnym sławy”. Było to możliwe dzięki temu, że wskutek wzajemnych kontaktów i powiązań „uczyły się one w je d n e j s z k o le”, tak że „niezależnie od wszelkich różnic narodowych w obyczajach i językach, literatura i nauka europejska [...] [przyjęły] w s p ól n y k i e r u n e k ${ }^{12}$. Zaistniała nowa forma życia, której szlak powstania naznaczony zostal „ch r ześcijańską dobrocią serca” ${ }^{13}$. Napotykamy tu idee

\footnotetext{
10 Ibidem, s. 490

11 Ibidem, s. 492.

12 lbidem, s. 501 i n.

13 Ibidem, s. 502.
} 
przypisywane zazwyczaj Novalisowi w związku z jego rozprawą Chrześcijaństwo i Europa (Christenheit und Europa) z roku 1799. Dalsze koleje losu Europy Herder pokazuje jednak inaczej niż Novalis we wspomnianym eseju. W ujęciu Herdera renesans nie był początkiem rozkładu, jak u Novalisa, lecz dał on poezji formę i reguły dzięki „p o n o w n e m u p r z e budzeniu Dawny ch". Na pierwszym miejscu Herder wymienia Petrarkę wraz z jego „przyjemną p o e z ją l u d o w ą”, przez którą rozumie zapewne Canzoniere, napisane przez Petrarkę po włosku. Petrarka stał się dla wielu wzorem do naśladowania, co Herder zdaje się postrzegać pozytywnie. Nie wolno jednak jego zdaniem zapominać, jak wielkie znaczenie dla europejskiej historii literatury miała poezja średniowieczna. Jako przykłady twórczego nawiązania do średniowiecza Herder przywołuje Dantego i Szekspira. W tak zwanych barbarzyńskich czasach poczyniono znaczące wynalazki, a większości z nich nie da się wyjaśnić przez odwołanie do „dawnych mistrzów”, lecz jedynie „poprzez styl myślenia narodu i jego smak w czasach pierwotnych oraz wiekach śred$\mathrm{n} \mathrm{i} \mathrm{ch"14}$. Pomimo niechęci do łaciny jako języka poezji Herder musi przyznać, że dzięki „nowszej poezji łacińskiej” ukonstytuowało się społeczeństwo,

jakiego epoki wcześniejsze jeszcze nie znały; we Włoszech, Hiszpanii, Portugalii, Francji, na Wyspach Brytyjskich, w królestwach północnych, w Inflantach, Polsce, Prusach, na Węgrzech, w Niemczech, Holandii itd. nie tylko wierszowano po łacinie, ale tu i ówdzie także powstawała prawdziwa poezja. Włochy, Francja, Niemcy, Polska, przede wszystkim Holandia miały mężów, którzy potrafili obchodzić się z laciną jak z językiem ojczystym i stworzyli w niej wiersze, jakie w każdym języku narodowym cieszyłyby się uwagą. Nawet ci wybitni, którzy nadali językowi i poezji swoich narodów doskonalszą formę, jej początki szlifowali po łacinie, o czym, poza Włochami, świadczą przykłady Miltona, Cowleya, Grotiusa, Heinsiusa, Opitza ${ }^{15}$.

Jednym słowem, także tu powstało poczucie pewnej europejskiej wspólnoty, choć dla Herdera istota literatury europejskiej opiera się na narodowych głosach w całej ich różnorodności. Oczekiwał on, że wykształcą się kolejne literatury narodowe, przede wszystkim na wschodzie i południu Europy ${ }^{16}$. Miał w tym, jak się niedługo miało okazać, wiele racji.

W swoich przemyśleniach Herder jest w dużej mierze spadkobiercą tzw. Querelle des Anciens et de Modernes (sporu starożytników z nowożytnikami), którego przedmiotem była przewaga lub podrzędność Współczesnych wobec Dawnych. Mimo wielkiego szacunku, jakim darzył Dawnych, czyli Greków, Herder opowiedział się za Współczesnymi. Wielokrotnie zaznaczal, że czasy antyczne nie mogą się powtórzyć, ponieważ obecnie wszystko stało się bardziej skomplikowane. Wraz z pojawieniem się na scenie historii nowych ludów prostotę zastąpiła różnorodność i należy być zadowolonym - zdaje się on sądzić - że w Europie zaistniało pewne poczucie wspólnoty lub że do powstania takiego poczucia może dojść niebawem.

August Wilhelm Schlegel w początkowych zdaniach swoich berlińskich Wykładów o literaturze pięknej i o sztuce (Vorlesungen über schöne Literatur und Kunst) z lat 1801-1804

\footnotetext{
14 Ibidem, s. 517.

15 Ibidem, s. 515.

${ }^{16}$ Nie wolno zapominać, ze Herder wykluczył z Europy trzy narody: Żydów, którzy według niego powinni się zasymilować, Cyganów, którzy rzekomo nadają się jedynie do "militarnego chowu”, oraz Turków, którzy jakoby nie mieli czego szukać w Europie (zob. K. Sauerland, „Die fremden Völker in Europa”. Herders unpolitische Metaphern und Bilder zu den höchst politischen Begriffen Volk und Nation, [w:] Unerledigte Geschichten. Der literarische Umgang mit Nationalität und Internationalität, red. G. von Essen i H. Turk, Göttingen 2000.
} 
określił „poezję głównych narodów nowej Europy” mianem twórczości romantycznej. Przez narody główne rozumiał Hiszpanów ${ }^{17}$, Włochów, Francuzów, Anglików i Niemców. Później dołączyła jeszcze Portugalia ${ }^{18}$. Narody Europy Środkowo-Wschodniej oraz Wschodniej, jak Węgrzy, Polacy i Rosjanie, nie są dla niego głównymi narodami. Nie przyczyniły się zdaniem Schlegla w niczym do powstania literatury europejskiej. Literatura romantyczna zrodziła się według niego z centrum średniowiecza. Duch średniowiecza miał cechować się cnotami rycerskimi i chrześcijańskimi. Nie wyklucza to jednak wpływów obcych, przede wszystkim arabskich, którym wiele zawdzięcza Południe - Hiszpania i Włochy. W wykładach berlińskich Schlegel używał pojęcia „nowej Europy”, przez co rozumiał Europę chrześcijańską, i z tego powodu wykluczył z niej Turków, określając ich mianem „śmiertelnych wrogów chrześcijaństwa” ${ }^{19}$, podobnie zresztą jak to zrobił Herder. Europa Wschodnia została przez Schlegla zaledwie uwzględniona, przy czym Rosja jego zdaniem ku Europie zwraca się dopiero od czasów Piotra I. W przeciwieństwie do Herdera Schlegel nie oczekiwał jednak od Wschodu nowych impulsów. Najwyraźniej europejskie jest według niego jedynie to, co znajduje „europejskie uznanie”, jak można wywnioskować z datowanego na 1825 rok Zarysu europejskości literatury niemieckiej (Abriß von den europäischen Verhältnissen der deutschen Literatur $)^{20}$.

Gdy Friedrich Schlegel, brat Augusta Wilhelma, prowadził swoje wykłady z historii literatury w Wiedniu, uznał za zrozumiałe samo przez się, by rozpoczęły się one od antyku. W końcu od młodości zajmował się literaturą starogrecką - wystarczy przypomnieć słynny esej O studiowaniu poezji greckiej (Über das Studium der griechischen Poesie) z roku 1795 i starał się nawet pokazać, że już w Grecji odnajdujemy nowoczesne formy artystyczne. Około roku 1812 wskazywanie wspólnego podłoża nowoczesnej literatury romantycznej należało już do oczywistości. Jedynie nieliczni utrzymywali jeszcze, że antyczni poeci przewyższali współczesnych. Także Friedrich Schlegel, podobnie jak jego brat, posługuje się pojęciem „nowej”, względnie „nowszej” Europy, zrodzonej wraz ze zwycięstwem chrześcijaństwa; wskazuje jednak na znacznie starsze tradycje, szczególnie na Stary Testament, który stanowi w czystej formie dziedzictwo Hebrajczyków. Nie został on na długo zapomniany i przyćmiony przez nowszą poezję, jak to się stało w wypadku tradycji innych ludów ${ }^{21}$. Chrześcijaństwo zawdzięcza jednak wiele, jak utrzymuje Schlegel, również wpływom z obszaru azjatyckiego, tj. z Orientu, w tym z Indii. Najistotniejsze wszakże dla literatury nowej Europy jest to, że doszło do powstania interesującej mieszanki duchowości chrześcijańsko-łacińskiej i przekazów pierwotnych, właściwych poszczególnym narodom ${ }^{22}$. Dzięki dawnym przekazom, które niestety jednak w niemałej mierze uległy zatarciu, „duch poezji” mógł się w nowej Europie przebić. Żaden naród nie może bowiem dorobić się własnej po-

17 A. W. Schlegel przybliżył niemieckiej publiczności dzieło Calderona, tłumacząc dramaty Don Fernando i Don Enrique. Jego studia nad literaturą hiszpańską sięgają okresu getyńskiego, kiedy był studentem między innymi Bürgera, znawcy tej literatury.

${ }^{18}$ A. W. Schlegla zainspirował jego brat Friedrich, który odkrył w Paryżu dzieła Luísa Vaz de Camõesa, portugalskiego autora z XVI wieku, i pisał o nim w swoim periodyku „Europa”. A. W. Schlegel przełożył pieśń szesnastą z cyklu Os Lusíadas oraz kilka wierszy Camõesa (opublikował je w tomie Blumensträuße aus dem Italienischen, Spanischen und Portugiesischen, Berlin 1804).

19 A. W. Schlegel, Geschichte der romantischen Literatur, red. L. Edgar, Stuttgart 1965, s. 20.

20 Opublikowany w: Europa. Analysen und Visionen der Romantiker, red. P. M. Lützeler, Frankfurt am Main 1982 , s. 374.

${ }_{21}$ Zob. F. Schlegel, Geschichte der alten und neuen Literatur, red. H. Eichner, t. 6, Paderborn 1961, s. 100.

22 Ibidem, s. 150, 170. 
ezji, jeśli nie posiada swoich „poetyckich praczasów”. Zarówno Grecy (w odróżnieniu od Rzymian), jak też nowoczesne narody dysponowały zawsze - zdaniem Schlegla - taką przeszłością. Schlegel prowadzi swoich słuchaczy (a następnie czytelników: w roku 1815 wykłady w rozszerzonej formie ukazały się drukiem) przez literaturę europejską aż do współczesności, tj. do de Maistre’a, do młodego wówczas, urodzonego w roku 1782 Lamennais'go, a przede wszystkim do Schillera, Goethego i Tiecka.

Poszerzenie pojęcia literatury europejskiej o współczesne literatury krajów Północy oraz Europy Środkowo-, Południowo-Wschodniej i Wschodniej nastąpiło w języku niemieckim w wieku XIX, gdy powstawały na tych obszarach nowoczesne literatury narodowe. W Europie Zachodniej, w tym w Niemczech, poszczególni autorzy przybliżani byli szerszemu kręgowi czytelniczemu początkowo poprzez antologie ${ }^{23}$, zanim przekładów doczekały się dzieła w całości. Najwcześniej za niekwestionowaną część nowej literatury europejskiej uznano w Niemczech literaturę skandynawską. Ibsen stworzył w Podporach społeczeństwa wręcz nowy gatunek, mianowicie naturalistyczny dramat społeczny, który rozpowszechnił się następnie w literaturze Europy.

31 stycznia 1827 roku Goethe miał wyjaśnić Eckermannowi: „Literatura narodowa jest pojęciem, które dziś niewiele mówi, kiedy nadchodzi era literatury powszechnej dla całej ludzkości i każdy musi współdziałać, aby nadejście tej ery przyśpieszyć”24. Wzorce jednak, dodał, znaleźć można jedynie u „dawnych Greków”2s. Mamy tu do czynienia z zadziwiającym zwrotem ku antykowi. Nowoczesna literatura jednoczy ludzkość, lecz przykładem dla niej pozostaje klasyczna literatura grecka. W innym miejscu Goethe konstatuje: „wielki pożytek, wynikający ze wspólnoty literackiej całego świata, pożytek, który coraz bardziej będzie się ujawniał”, polega na tym, że w obliczu obecnych „ścisłych stosunków pomiędzy Francuzami, Anglikami i Niemcami” dochodzi do wzajemnych korekt sądów i poglądów ${ }^{26}$. Należy mieć nadzieję na powstanie we „współczesnych, burzliwych” czasach literatury światowej. Wprawdzie nie istnieje ona jeszcze, ale jej narodziny to tylko kwestia $\mathrm{czasu}^{27}$. Znajduje się już w natarciu, czytamy następnie w liście do Zeltera z 4 marca 1829 r. ${ }^{28}$ Literatura światowa to dla Goethego jednoznacznie literatura współczesna, w obrębie której odbywa się wymiana kulturowa. Wielka rola przypada tu tłumaczom, o których niemiecki poeta mówi: „Więc każdy tłumacz podejmuje trud pośrednictwa w owym ogólnoduchowym handlu i wspiera wzajemną wymianę. Niezależnie bowiem od tego, co się mówi o niedostatkach przekładów, tłumaczenie jest i pozostanie jednym z najważniejszych i najgodniejszych zajęć w powszechnym światowym obiegu"29.

${ }^{23}$ Interesujące są w tym kontekście między innymi publikacje grupy badawczej „Przekłady Literackie” z Getyngi, w tym pozycje redagowane przez Helgę Eßmann: Weltliteratur in deutschen Versanthologien des 19. Jahrhunderts, Berlin 1996 oraz Übersetzte Literatur in deutschsprachigen Anthologien: eine Bibliographie, Stuttgart 2001.

24 J. P. Eckermann, Rozmowy z Goethem, tłum. K. Radziwiłł i J. Zeltzer, Warszawa 1960, t. 1, s. 333.

${ }^{25}$ Ibidem.

26 Ibidem, s. 416.

27 O szkocko-angielskich przeglądach Goethe pisał w roku 1828: „Te czasopisma, zdobywające stopniowo coraz liczniejszą publiczność, najbardziej przyczynią się do powstania oczekiwanej ogólnej literatury światowej [...]" (J. W. von Goethe, Werke: Hamburger Ausgabe In 14 Bänden, red. E. Trunz, München 1999, t. 12, s. 362 i następne).

${ }_{28}$ Goethe mówi w tym miejscu o "ofensywie literatury światowej” (ibidem, s. 363).

${ }^{29}$ Ibidem, s. 353. Na temat pojęcia literatury światowej u Goethego istnieje obszerna literatura. Zwróćmy tu uwagę na następujące pozycje: F. Strich, Goethe und die Weltliteratur, Bern 1946; H. J. Schrimpf, Goethes Begriff der Weltliteratur. Essay, Stuttgart 1968; V. Lange, Nationalliteratur und Weltliteratur, "Goethe-Jahrbuch" 1971, 
Na kontekst historycznojęzykowy, w jakim powstał termin użyty przez Goethego, wskazał ostatnio Manfred Koch. W początkach XIX wieku w niemczyźnie pojawiły się złożenia z komponentą Welt (świat); mówiono o światowej historii, światowych dziejach oraz o światowym rynku (Weltgeschichte, Weltmarkt). Pojęcie Weltliteratur nie jest zatem odosobnionym i całkowicie oryginalnym pomysłem poety, lecz nawiązuje do pewnej językowej tendencji ${ }^{30}$. Uzupełniając tę uwagę Kocha, można przywołać Zygmunta Łempickiego, który już wiele dziesięcioleci wcześniej, w roku 1920, wskazywał w swojej historii literatury niemieckiej na słowo Weltgeschichte, ukute w 1773 roku przez Augusta Ludwiga von Schlözera. Jednak zainteresowanie tym fenomenem słowotwórczym nie powinno przesłaniać faktu, że około roku 1800 w centrum uwagi niemieckich twórców i intelektualistów znalazło się bez wątpienia pojęcie Europy, i to w ramach tego właśnie pojęcia doszło do dyskusji o koncepcji literatury, mianowicie literatury europejskiej. Należy też zaznaczyć, że Goethe wzmiankuje pojęcie Weltliteratur, o czym się zapomina, niejako na marginesie $\mathrm{w}$ rozmowie z Eckermannem. Pojęcia tego użył prawdopodobnie pamiętając o Wielandzie, właściwym twórcy tego terminu. Autorytet Goethego oraz tendencja niemieckiego literaturoznawstwa do upatrywania w poecie ojca założyciela myślenia w kategoriach literatury światowej sprawily jednak, że to Goethemu powszechnie przypisuje się w tej mierze sprawstwo. Wieland w roku 1790 podarował księciu Karolowi Augustowi egzemplarz własnego przekładu Horacego z odręczną dedykacją, w której dokonał po namyśle poprawki: pożądane cechy „uczoności i ogłady” zastąpił „literaturą światową”, mając na myśli cnotę, jaka powinna cechować człowieka obytego i wszechstronnie wykształconego ${ }^{31}$. Goethe zapewne podjąl to wyrażenie, przesuwając znaczenie z cnoty charakteru na komunikację.

W roku 1848 Johannes Scherr wydał Bildersaal der Weltliteratur (Panoramę literatury światowej), rodzaj antologii tłumaczeń z wielu języków i kręgów kulturowych. We wstępie odwołał się do pojęcia literatury światowej Goethego, a zarazem podkreślal, iż prezentując antologię, pragnie „przedłożyć obszerną historię literatury w przykładach”32. Życzyłby sobie, aby antologia znalazła szeroki krąg czytelników. Rzeczywiście w połowie wieku XIX dał się w Niemczech zauważyć wzrost zainteresowania przekładami z najróżniejszych języków, zwłaszcza że wydawcy zaczęli oferować tanie, popularne wydania książek. Seria Das belletristische Ausland (Literatura piękna za granicą) liczyła w okresie między 1843 a 1865 rokiem 3618 tomów ${ }^{33}$. Jednak w języku niemieckim pojęcie nowej literatury europejskiej zostało zastąpione przez literaturę światową dopiero kilka dziesięcioleci później; dokonało się to w wieku XX. Fakt ten nie miał, niestety, w zasadzie wpływu na sposób pisania historii literatury. Podczas gdy obaj Schleglowie starali się skonstruować europejską historię literatury, która respektowałaby pojmowanie Europy jako duchowej jedności, od połowy XIX wieku nauka o literaturze podzieliła się w Niemczech na dyscypliny skoncentrowane na perspek-

\footnotetext{
t. 33, s. 15-30; D. Lamping, Die Idee der Weltliteratur. Ein Konzept Goethes und seine Karriere, Stuttgart 2010 oraz C. D. Conter, Weltliteratur und Literärgeschichte. Über die Verdrängung europäischer Literaturgeschichtsschreibung im 19. Jahrhundert der nationalen Identitätsbildung, „Euphorion” 2007, t. 101, s. 87-103.

30 M. Koch, Weimaraner Weltbewohner: Zur Genese von Goethes Begriff ,Weltliteratur', Berlin 2002, s. 43 i następne.

${ }^{31}$ M. Koch, Goethes, Weltliteratur' - Ein ambivalenter Erwartungsbegriff, "Zeitschrift für Soziologie” (zeszyt specjalny pt. Społeczeństwo światowe) 2005, s. 53.

32 J. Scherr, Bildersaal der Weltliteratur, Stuttgart 1885, t. 1, s. 6.

${ }_{33}$ Zob. Ch. Haug, Buchserien und Anthologien. Wirkungsmächtige Medien zur Etablierung und Durchsetzung von ausländischen Literaturen in Deutschland im 19. Jahrhundert, http://www.iaslonline.de/index.php?mode= context\&keyword=\%DCbersetzung (dostęp: 24.09.2015).
} 


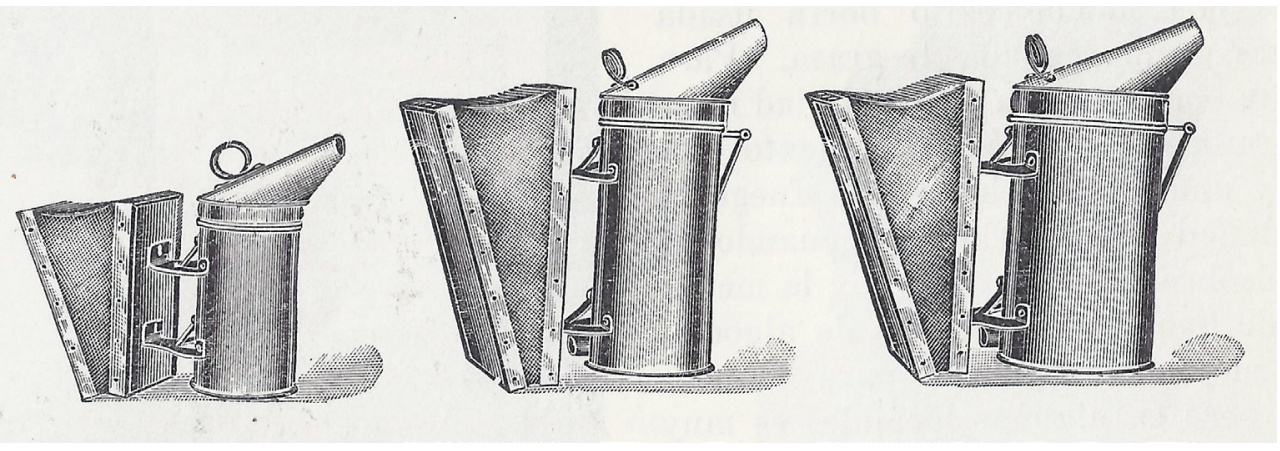

tywie narodowej. Obecnie istnieją katedry komparatystyki, gdzie naucza się porównawczo w najlepszym wypadku dwóch lub trzech literatur narodowych. Kompetencje językowe były około roku 1800 większe niż obecnie, nawet jeśli dotyczyło to nielicznych. Dziś bywa trudno nawet o owych nielicznych. W roku 1985 zaproponowałem w referacie przekazanym na Międzynarodowy Kongres Germanistyczny w Getyndze (w którym nie mogłem niestety uczestniczyć fizycznie z powodu wydanego przez urzędy PRL zakazu wyjazdu), aby ująć w germanistyce problem narodowej historii literatury na nowo. Taka historia literatury mogłaby za punkt odniesienia przyjąć świadomość literacką panującą w danym okresie historycznym na danym obszarze. Badacze powinni zatem zainteresować się, co stanowiło literaturę żywą i istotną dla czytelników, zwłaszcza dla środowisk tworzących życie intelektualne.

Na przełomie wieków XIX i XX byli to Francuzi, kilku Skandynawów, Dostojewski, Tołstoj, Goethe, Nietzsche, Hauptmann etc. W okresie po II wojnie światowej najwięcej do powiedzenia mieli egzystencjaliści, Hemingway i Kafka, nieco później Ionesco i Beckett. Ponieważ mniej więcej od XIX stulecia już nie zakładano znajomości języków obcych jako zrozumiałej sama przez się, podstawą takiej historii literatury z powodzeniem mogłyby być przekłady. Tego typu ujęcie w dużej części sprawiałoby wrażenie europejskiej, względnie europocentrycznej części literatury światowej. Zobaczylibyśmy wtedy, że takie postaci, jak Dostojewski, Tołstoj, Jacobsen czy d'Annunzio miały dla literatury niemieckiej większe znaczenie niż Spielhagen czy Fontane lub niejeden późniejszy autor niemiecki. Jeszcze dziś często tęsknię za lekturą Flauberta czy Dostojewskiego, zamiast przymusu czytania któregoś z autorów niemieckich ledwie znanych za granicą, należących po prostu tylko do narodowej historii literatury. Także studentom poleciłbym inne lektury niż te, które muszą czytać do egzaminu. Mam świadomość, że taka historia „świadomości literackiej”, jak ją określam z braku lepszego terminu, jeszcze długo będzie czekała na swojego autora. Wszyscy jesteśmy wykształceni zbyt narodowo. Ani z domu, ani ze szkoły czy uniwersytetu nie wynosimy rozumienia literatury jako literatury światowej. W zasadzie nie studiujemy literatury jako literatury, ale jako germanistykę, tj. musimy przerobić pewien specyficzny kanon literacki, określany jako literatura niemiecka. Inne filologie mają do zaliczenia inne kanony. Następstwem tego stanu rzeczy jest to, że literatura jako zjawisko ponadnarodowe musi szukać sobie miejsca wśród pisarzy, krytyków i lektorów wydawnictw. Dzięki nim, a przede wszystkim dzięki czytelnikom, żyje ona nadal, nie została wyeliminowana przez tak zwane literatury narodowe ${ }^{34}$.

${ }^{34}$ K. Sauerland, Gibt es eine nationale Literaturgeschichte?, [w:] Kontroversen, alte und neue, Akten des VII. Internationalen Germanisten-Kongresses Göttingen 1985, red. A. Schöne, Tübingen 1986, t. 11, s. 113 i n. 
Gdybyśmy pisali i nauczali takiej historii literatury, pojawiłaby się możliwość, aby w danym kraju przynajmniej częściowo uchwycić funkcjonującą w nim „literaturę światową”. Do początków XX wieku rozumieliśmy pod tym pojęciem w naszym obszarze kulturowym, jak to wynika z powyższej analizy, przede wszystkim literaturę europejską.

Przełożyła Monika Tokarzewska

\section{Bibliografia}

Conter Claude D., Weltliteratur und Literärgeschichte. Über die Verdrängung europäischer Literaturgeschichtsschreibung im 19. Jahrhundert der nationalen Identitätsbildung, „Euphorion” 2007, t. 101.

Eckermann Johann Peter, Rozmowy z Goethem, tłum. Krzysztof Radziwiłł i Janina Zeltzer, Warszawa: PIW, 1960.

Europa. Analysen und Visionen der Romantiker, red. Paul Michael Lützeler, Frankfurt am Main: Insel-Verlag, 1982.

Goethe Johann Wolfgang von, Werke: Hamburger Ausgabe In 14 Bänden, red. Erich Trunz, München: Deutscher Taschenbuch Verlag, 1999.

Haug Christine, Buchserien und Anthologien. Wirkungsmächtige Medien zur Etablierung und Durchsetzung von ausländischen Literaturen in Deutschland im 19. Jahrhundert, http://www.iaslonline.de/ index.php? mode $=$ context\&keyword=\%DCbersetzung (dostęp: 24.09.2015).

Herder Johann Gottfried, Briefe zur Beförderung der Humanität (Werke in zehn Bänden, t. 7), red. Hans Dietrich Irmscher, Frankfurt am Main: Deutscher Klassiker Verlag, 1991.

Koch Manfred, Weimaraner Weltbewohner: Zur Genese von Goethes Begriff ,Weltliteratur', Berlin: de Gruyter, 2002.

— Goethes ,Weltliteratur' - Ein ambivalenter Erwartungsbegriff, „Zeitschrift für Soziologie” 2005.

Lamping Dieter, Die Idee der Weltliteratur. Ein Konzept Goethes und seine Karriere, Stuttgart: Kröner, 2010.

Lange Victor, Nationalliteratur und Weltliteratur, „Goethe-Jahrbuch” 1971, t. 33.

Opitz Martin, Buch von der Deutschen Poeterey, Halle: Niemeyer, 1955.

Sauerland Karol, „Die fremden Völker in Europa”. Herders unpolitische Metaphern und Bilder zu den höchst politischen Begriffen Volk und Nation, [w:] Unerledigte Geschichten. Der literarische Umgang mit Nationalität und Internationalität, red. Gesa von Essen i Horst Turk, Göttingen: Wallstein Verlag, 2000.

— Gibt es eine nationale Literaturgeschichte?, [w:] Kontroversen, alte und neue, Akten des VII. Internationalen Germanisten-Kongresses Göttingen 1985, red. Albrecht Schöne, Tübingen: Niemeyer, 1986.

Scherr Johannes, Bildersaal der Weltliteratur, Stuttgart: Kröner, 1885.

Schlegel August Wilhelm, Geschichte der romantischen Literatur (Kritische Schriften und Briefe, t. 4), red. Lohner Edgar, Stuttgart: Kohlhammer, 1965.

Schlegel Friedrich, Geschichte der alten und neuen Literatur, red. Hans Eichner, t. 6, Paderborn: Schöningh, 1961.

Schrimpf Hans Joachim, Goethes Begriff der Weltliteratur. Essay, Stuttgart: Metzler, 1968.

Strich Fritz, Goethe und die Weltliteratur, Bern: Francke, 1946.

Weltliteratur in deutschen Versanthologien des 19. Jahrhunderts, red. Helga Eßmann, Berlin: Erich Schmidt, 1996

Übersetzte Literatur in deutschsprachigen Anthologien: eine Bibliographie, red. Helga Eßmann, Stuttgart: Hiersemann, 2001. 